Original Research

\title{
A Novel Structure Applied to the Permeable Brick Paving System and Its Decontamination Performance
}

\author{
Zizeng Lin*, Hai Yang, Huiming Chen, Zhaoqinliu, Xinyu Ouyang \\ College of Civil Engineering, Nanjing Forestry University, 159 Longpan Road, Nanjing 210037, PR China
}

Received: 24 November 2019

Accepted: 11 March 2020

\begin{abstract}
To improve the pollutant removal efficiency of the permeable brick paving system, a novel structure applied to the base layer was introduced, and its decontamination performance was researched. Suspended solids (SS), chemical oxygen demand (COD), ammonia nitrogen $\left(\mathrm{NH}_{4}^{+}-\mathrm{N}\right)$, total nitrogen $(\mathrm{TN})$, total phosphorus $(\mathrm{TP})$ and heavy metals $(\mathrm{Cu}, \mathrm{Zn}$, and $\mathrm{Pb})$ in the influent and effluent were measured, and the role and mechanism of the fillers inside the novel structure were discussed by changing the type and size of the fillers. The results showed that the removal efficiency of the system using the frame structure was slightly lower than that of the cement concrete block. The removal efficiency results using different particles and materials showed that (I) The permeable brick system filled with small-diameter gravel was more effective than a system filled with large-diameter gravel, and the graded gravel of $3-15 \mathrm{~cm}$ exerted multiple filtering effects, owning the same effectiveness as the gravel with particles sizes of 3-5 cm. (II) The addition of zeolite and iron filings in the framework could effectively reduce $\mathrm{NH}_{4}^{+}-\mathrm{N}$ and $\mathrm{NO}_{3}^{-}-\mathrm{N}$, while the addition of fillers such as volcanic rocks rich in iron oxides improved the adsorption effect of COD. The study provides a new and more environmentally friendly alternative for the base layer of permeable brick paving system.
\end{abstract}

Keywords: well-shaped frame structure, fillers, pollutant removal rate, runoff

\section{Introduction}

In recent years, permeable brick paving systems have become one of the most frequently used low impact development (LID) techniques $[1,2]$. This infiltration-based technology comprises structural layers with relatively high porosity to allow rainwater to pass through its surface and underlying layers. Permeable

*e-mail: linzizeng@njfu.edu.cn brick pavements are composed of a permeable brick, aggregate subbases, and sometimes geotextiles and underdrains. Rainwater eventually infiltrates into the natural soil or discharges into a drainage system [3, 4].

The two major advantages of permeable brick paving systems are good hydrological effectiveness and the reduction of rainwater pollution. The significant environmental benefits of hydrological effectiveness are reducing the volume of rainwater runoff and recharging of ground water [5-8]. This requires that the permeable paving system has sufficient permeability, 
which is mainly related to its structure, that is, the surface and base courses of the permeable pavement; therefore, the materials comprising its various layers must be carefully selected to have adequate drainage properties [9, 10]. On the other hand, the materials comprising the various layers are closely related to the ability of the paving system to remove contaminants. First, the characteristics of the permeable pavement surface materials (PPSMs) are related to the efficiency of removing pollutants [11]. For example, research found that the average efficiency of removing SS in six common surface materials (porous asphalt, porous concrete, cement brick, ceramic brick, sand base brick, and shale brick) was nearly $90.0 \%$, and the efficiency of shale brick in removing $\mathrm{COD}, \mathrm{NO}_{3}{ }^{-} \mathrm{N}$, and $\mathrm{TN}$ was $88.2 \%, 35.1 \%$, and $17.5 \%$, respectively [12]. Second, the influence of the base material on the effluent water quality is greater than that of the surface materials since the base layer is the underlying structure of the system, which is the last treatment procedure of the effluent [13].

At present, the permeable brick paving system mainly uses gravel or cement concrete blocks as the base layer. There is accounted for some problems in these materials, such as the low bearing capacity of the crushed stone, and the application of the cement concrete block is very inconvenient because of its heavy weight. In addition, the loose gravel base has poor effectiveness in purifying the COD and nitrogen pollutants $[10,14$, 15], and the base layer of cement concrete blocks releases hydroxide ions $\left(\mathrm{OH}^{-}\right)$and carbonate ions $\left(\mathrm{CO}_{3}{ }^{2-}\right)$, which raises the $\mathrm{pH}$ of the runoff $[3,16]$. Some research found that the base layer accounted for approximately $2 / 3$ of the permeable pavement in volume, but the contribution rate of the base layer to runoff pollutant removal was only $10 \%-25 \%$ [14]. This poor mitigation effectiveness indicated that the base layer had not been fully utilized.
Therefore, there is a need for improvement in the base layer, which is mainly because the base layer has an important influence on the removal rate of pollutants.

To increase the pollution-removal contribution by the base layer and further improve effluent quality, a frame base layer with a Chinese character "well" was introduced into the permeable brick paving system, and different fillers could be used inside the structure to amend the permeable brick paving system. There are three main advantages to adopting this strategy: one is to reduce the use of cement concrete and its negative impact on water quality; the second is that the flow rate can be adjusted by changing the diameter of the filler; and the third is the removal of contaminants can be adjusted by the filtration, retention and adsorption characteristics of the fillers.

In this study, a permeable brick paving system is constructed using ceramic permeable brick as the surface layer and a "well"-shaped frame as the base layer. Gravel composed of four different particle sizes and zeolite, volcanic rock and iron filings with the same particle sizes are added to the base layer. The role and mechanism of the fillers in the removal of contaminants are analyzed by changing the type and size of the filler. The objectives and novelties of this research are to explore the feasibility of introducing the well structure in the permeable brick paving system and to research its performance in the removal of pollutants.

\section{Materials and Methods}

Experimental Setup

The test device for the permeable brick paving system is shown in Fig 1. The dimensions of the device were $0.8 \mathrm{~m} \times 0.8 \mathrm{~m} \times 0.5 \mathrm{~m}$. A total of 16 permeable bricks

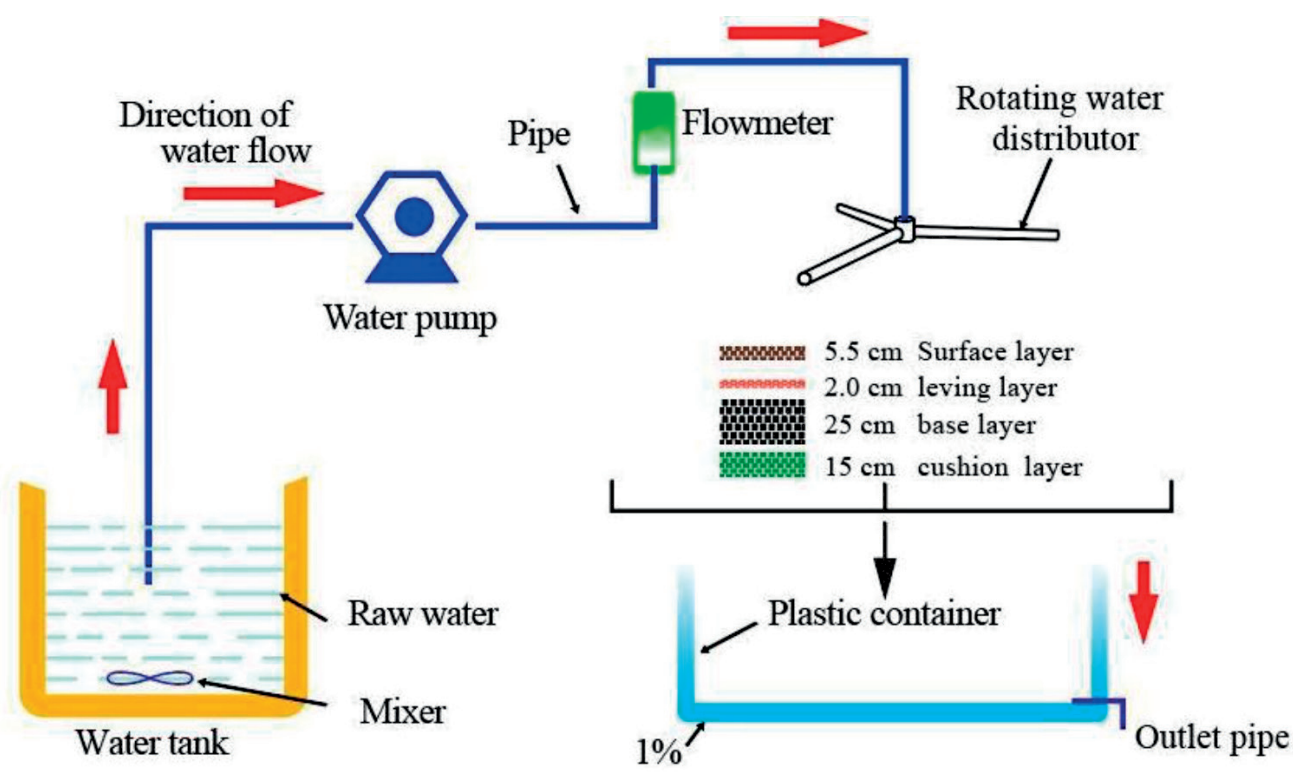

Fig. 1. Schematic of the device. 


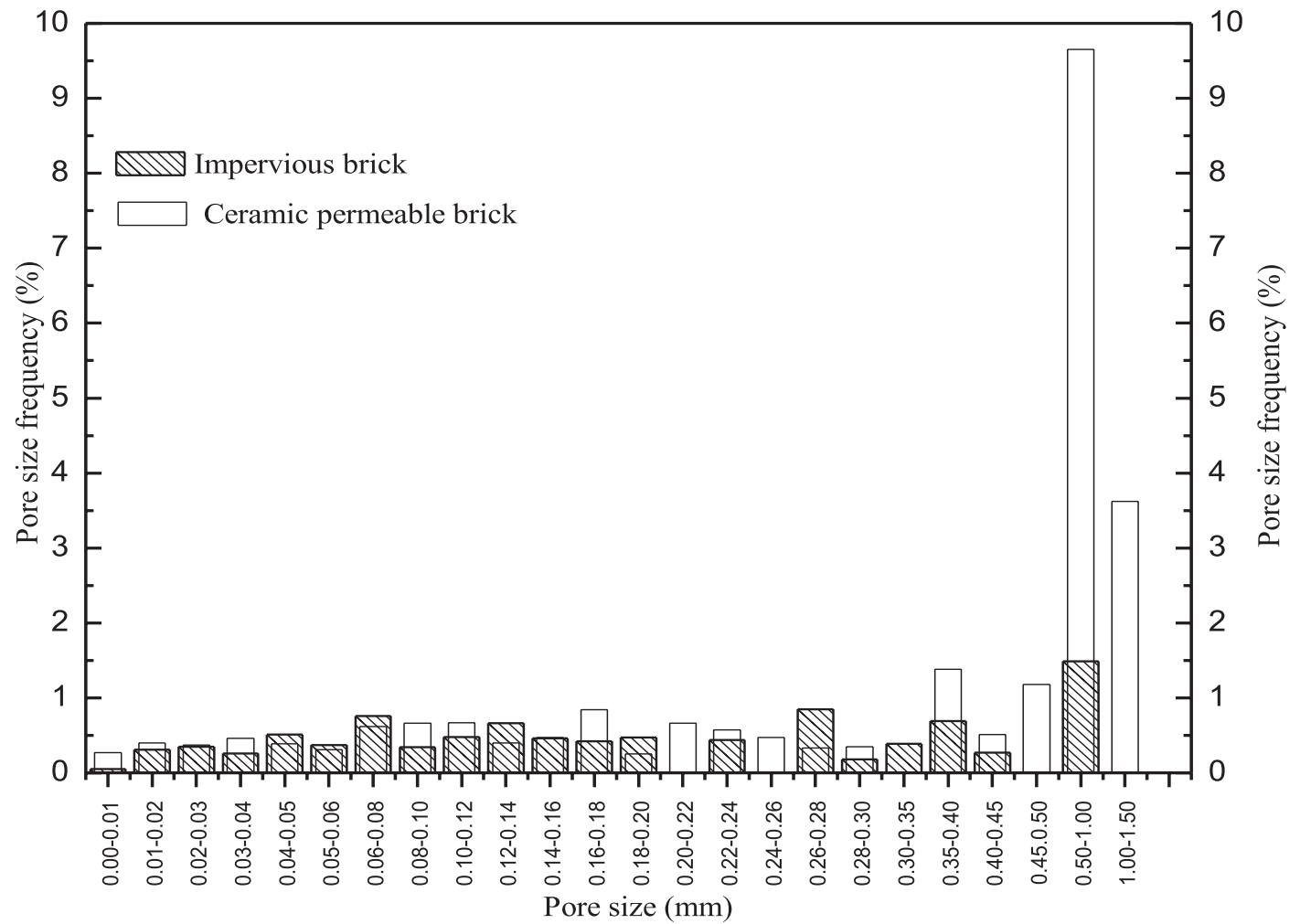

Fig. 2. Pore structure distribution of ceramic permeable brick.

measuring $20 \mathrm{~cm} \times 20 \mathrm{~cm} \times 5.0 \mathrm{~cm}$ were placed in close proximity. One $10 \mathrm{~mm}$-diameter outlet pipe was set at the bottom of the permeable brick system. An overflow pipe with a diameter of $10 \mathrm{~mm}$ was set at the top of the device.

The prepared rainwater was lifted by a water pump and evenly distributed by a rotating water distributor. The rainwater was sampled after passing through the ceramic permeable brick and the paving system. Samples were taken every 10 minutes for a total of 2 hours while the outlet pipe of the pavement had a stable outflow. The water sample was collected using a $500 \mathrm{~mL}$ polyethylene sampling bottle, and all samples were measured within 48 hours.

\section{Materials}

\section{Pervious Brick}

The ceramic permeable bricks measured $20 \mathrm{~cm} \times 20$ $\mathrm{cm} \times 5.5 \mathrm{~cm}$ were purchased from Youbang (Yi xing) Building Materials Co., Ltd. The main properties of the ceramic bricks, such as splitting tensile strength, permeability coefficient, frost resistance, slip resistance and porosity, all met the requirements of the Chinese national standard, permeable paving bricks and permeable paving flags (GB/T 25993-2010). The main properties are shown in Table 1, and the chemical composition is shown in Table 2 .

Table 1. The main properties of ceramic permeable brick.

\begin{tabular}{|c|c|c|c|c|c|c|}
\hline \multirow{2}{*}{ Index } & \multicolumn{2}{|c|}{$\begin{array}{c}\text { Splitting tensile strength } \\
(\mathrm{MPa})\end{array}$} & $\begin{array}{c}\text { Permeability coefficient } \\
(\mathrm{cm} / \mathrm{s})\end{array}$ & $\begin{array}{c}\text { Frost resistance } \\
(\%)\end{array}$ & $\begin{array}{c}\text { BNP } \\
\text { GB/T25993-2010 }\end{array}$ & $\begin{array}{c}\text { Porosity } \\
(\%)\end{array}$ \\
\hline Ceramic brick & 5.3 & 4.7 & $3.1 \times 10^{-2}$ & $\begin{array}{c}\text { Strength loss } \\
\text { rate } \leq 20\end{array}$ & $\geq 65$ & $\geq 15$ \\
\hline
\end{tabular}

BPN, British Pendulum Number

Table 2. Chemical composition of ceramic permeable brick.

\begin{tabular}{|c|c|c|c|c|c|c|c|c|}
\hline Composition & $\mathrm{SiO}_{2}$ & $\mathrm{Al}_{2} \mathrm{O}_{3}$ & $\mathrm{CaO}$ & $\mathrm{K}_{2} \mathrm{O}$ & $\mathrm{Fe}_{2} \mathrm{O}_{3}$ & $\mathrm{MgO}$ & $\mathrm{Na}_{2} \mathrm{O}$ & $\mathrm{Else}$ \\
\hline Ceramic brick & 69.32 & 17.50 & 2.58 & 2.23 & 1.42 & 1.32 & 3.98 & 1.65 \\
\hline
\end{tabular}


a)

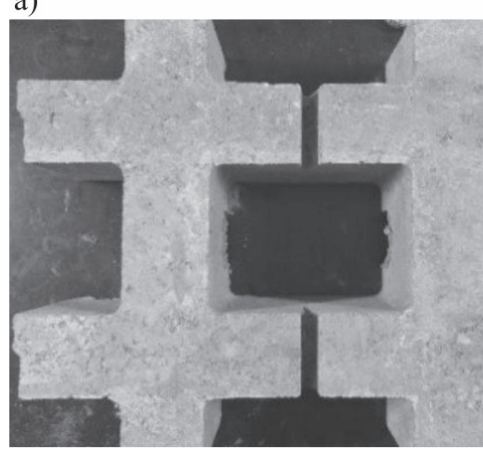

b)

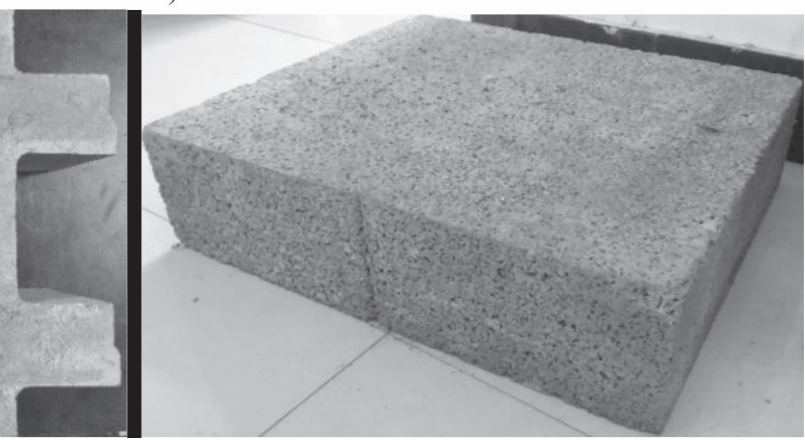

Fig. 3. Different structures of base layer: a) the well-shaped frame structure, b) cement concrete block.

Permeability coefficient of permeable brick was $3.1 \times 10^{-2} \mathrm{~cm} / \mathrm{s}$ much larger than the national standard at $2.0 \times 10^{-2} \mathrm{~cm} / \mathrm{s}$. From the pore structure distribution of cross section (Fig 2), ceramic permeable brick had a higher proportion of pores in the $0.5-1.5 \mathrm{~mm}$ specification than impervious bricks, this might be the reason for the higher permeability coefficient of ceramic permeable brick.

\section{Base Layer}

The novel structure applying to the base layer employed a well-shaped frame with a symmetrical shape measuring $40 \mathrm{~cm} \times 40 \mathrm{~cm} \times 25 \mathrm{~cm}$ (Fig 3a), the fillers were placed in the spare space where the spare ratio is approximately $40 \%$. The dimensions of cement concrete block was $60 \times 60 \mathrm{~cm} \times 25 \mathrm{~cm}$, which was a heavy concrete cube with high compressive strength up to $50 \mathrm{MPa}$ (Fig 3b)

The fillers of gravel, zeolite, volcanic rock and iron filings inside the well-shaped frame structure were purchased from Nanjing local building market, the photo of the typical fillers is showed in Fig. 4.

\section{Structure Form}

Eight structural forms constructed using two structures and four fillers were named facilities 1-8, and the detailed structures are shown in Table 3. Meanwhile, in order to better study the removal effect of the frame structure, the removal efficiency of the ceramic permeable brick was determined to distinguish the role of surface brick in the whole system.

\section{Simulated Rainfall}

The test was based on the 2-hour rainfall duration and 20-year repetition period in Nanjing as the experimental rainfall condition. The concentrations of various pollutants in the artificial rainwater with reference to the actual road rain concentration in Nanjing were shown in Table 4.

\section{Test Methods}

According to linear transverse winding test of Standard Test Method for Microscopical Determination of Parameters of the Air-Void System in Hardened Concrete (ASTM C457), Pore structure distribution was measured by using air void analyzer (Rapid air 457, Germany). According to the Chinese National Standard Methods (SEPA of China 2002), SS was determined by the gravimetric method (GB 11901-89), COD was determined by the fast digestion-spectrophotometric method (HJ/T 399-2007), concentrations of $\mathrm{NH}_{4}^{+}-\mathrm{N}$, $\mathrm{TN}$, and TP were determined by the spectrophotometric method, and concentrations of $\mathrm{Zn}, \mathrm{Cu}$ and $\mathrm{Pb}$ were determined by atomic absorption spectrophotometry.

The main experimental equipment was as follows: air void analyzer (Rapid air 457, Germany), UV a)

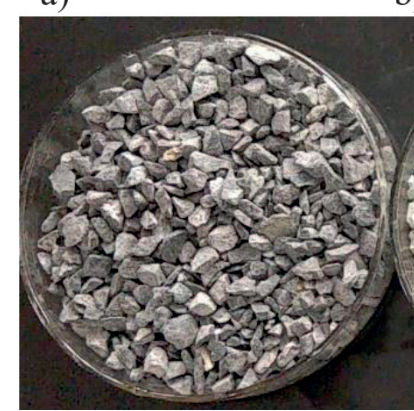

b)

(b)

c) d)

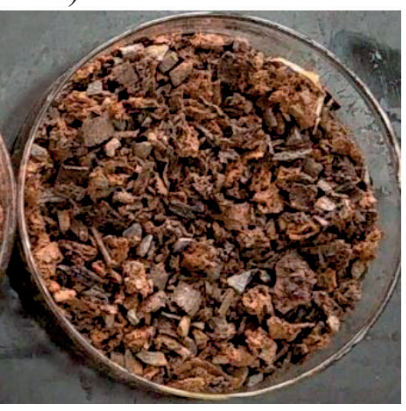

Fig. 4. Schematic diagram of the fillers inside the well-shaped frame structure: a) gravel, b) zeolite, c) volcanic rock, d) iron filings. 
Table. 3 The detailed structures of the facilities

\begin{tabular}{|c|c|c|c|c|}
\hline Item & Surface & Leveling & Base & Cushion \\
\hline 0 & \multirow{9}{*}{$\begin{array}{l}\text { Ceramic permeable } \\
\text { brick }\end{array}$} & - & - & - \\
\hline 1 & & \multirow{8}{*}{$\begin{array}{c}\text { Coarse sand with } \\
\text { diameter } 0.5-1.0 \\
\mathrm{~mm}\end{array}$} & Gravel with diameter 3-5 mm & \multirow{8}{*}{$\begin{array}{c}\text { Gravel with } \\
\text { diameter } 15-20 \mathrm{~mm}\end{array}$} \\
\hline 2 & & & Gravel with diameter 8-10 mm & \\
\hline 3 & & & Gravel with diameter $12-15 \mathrm{~mm}$ & \\
\hline 4 & & & Graded gravel with diameter 3-15 mm & \\
\hline 5 & & & Zeolite with diameter 3-5 mm & \\
\hline 6 & & & Volcanic rock with $3-5 \mathrm{~mm}$ & \\
\hline 7 & & & \multirow{2}{*}{$\begin{array}{l}\text { Iron filings with diameter } 3-5 \mathrm{~mm} \\
\text { cement concrete block }\end{array}$} & \\
\hline 8 & & & & \\
\hline
\end{tabular}

Table. 4 Concentration of runoff rainwater pollutants.

\begin{tabular}{|c|c|c|}
\hline Items & $\begin{array}{c}\text { Raw water } \\
(\mathrm{mg} / \mathrm{L})\end{array}$ & Reagent \\
\hline $\mathrm{SS}$ & 370 & Kaolin \\
\hline $\mathrm{TP}$ & 1.71 & $\mathrm{Na}_{2} \mathrm{HPO}_{4}$ \\
\hline $\mathrm{TN}$ & 11.4 & $\mathrm{NaNO}_{3}, \mathrm{NH}_{4} \mathrm{Cl}$ \\
\hline $\mathrm{COD}$ & 250 & $\mathrm{Glucose}$ \\
\hline $\mathrm{Ammonia}$ & 7.41 & $\mathrm{NH}_{4} \mathrm{Cl}$ \\
\hline $\mathrm{Cu}$ & 0.4 & $\mathrm{CuSO}_{4}$ \\
\hline $\mathrm{Zn}$ & 0.6 & $\mathrm{ZnSO}$ \\
\hline $\mathrm{Pb}$ & 0.5 & $\mathrm{~Pb}_{4}(\mathrm{Cl})_{2}$ \\
\hline
\end{tabular}

spectrophotometer (L5S, China), high-pressure steam sterilization pot (YX280A, China), peristaltic pump (MP-15RN, China), magnetic stirrer (Chijiu84-1, China) and atomic absorption spectrophotometer (TAS-990, China). All the water used in the experiment was ultra-pure water made by an ultra-pure water machine (Biosafer-20TAB, China).

\section{Results and Discussion}

\section{Feasibility of the Novel Structure}

The removal rates of pollutants for ceramic permeable brick and ceramic permeable brick paving systems filled by $3-5 \mathrm{~cm}$ gravel or cement concrete block are shown in Fig. 5. As shown in Fig. 5, several conclusions can be drawn.

Frist, the surface permeable brick played an important role in the removal of SS, TP and heavy metals, the removal contribution rates of surface permeable brick to pollutants of $\mathrm{SS}, \mathrm{TP}, \mathrm{NH}_{4}^{+}-\mathrm{N}, \mathrm{TN}$, $\mathrm{COD}, \mathrm{Zn}, \mathrm{Cu}$ and $\mathrm{Pb}$ for the system filled by cement concrete block were $86.35 \%, 80.07 \%, 15.00 \%, 3.76 \%$, $35.39 \%, 65.7 \%, 68.8 \%$ and $60.72 \%$, respectively. $\mathrm{Li}$ et al. found the average removal efficiency of SS was about $90.0 \%$ for six common surface materials (porous asphalt, porous concrete, cement brick, ceramic brick, sand base brick, and shale brick) because of physical interception. In terms of orthophosphate $\left(\mathrm{PO}_{4}^{3-}\right)$, the adsorption and ion exchange reaction of calcium, aluminum and iron ions in the brick with $\mathrm{PO}_{4}^{3-}$ in the rainwater formed precipitation granular metal salts, which were removed in the subsequent filtration process [12]. Heavy metals are present in stormwater in dissolved phases, but a large fraction of most metals are usually bound to suspended solids [17]. So the surface permeable brick played an important role in the removal of SS, TP and heavy metals.

The second, the permeable brick systems filled by gravel with a $3-5 \mathrm{~cm}$ particle size or cement concrete block all could effectively reduce the SS, TP, $\mathrm{Zn}, \mathrm{Cu}$ and $\mathrm{Pb}$ due to the double barrier caused by permeable brick in addition to gravel fillers or cement blocks. However, the removal rates for dissolved pollutants such as $\mathrm{NH}_{4}^{+}-\mathrm{N}, \mathrm{TN}$ and COD were inferior to that for $\mathrm{SS}, \mathrm{TP}$ and heavy metals, the reason for the difference in removal rate may be the discrepancy in removal mechanism of pollutants. These three pollutants were mainly removed by the adsorption of the brick materials $[10,14,18,19]$, while other pollutants were easily adsorbed on the SS and removed along with the filtering of the SS which was mainly achieved by the physical interception [18-22].

For different underlying structure forms of base layer, the removal rate of system filled by gravel with $3-5 \mathrm{~cm}$ diameter was slightly lower than that of the cement concrete block, the use of frame structure had little effect on pollutant removal. Besides, the $\mathrm{pH}$ of effluent reduced from 9.65 of the cement concrete block system to 7.80 of the frame structure system as a result of reducing the use of cement concrete, which significantly decreased the alkaline environment of the effluent. Hence, it is feasible to introduce the well structure in the permeable brick paving system considering the convenience of construction, little 

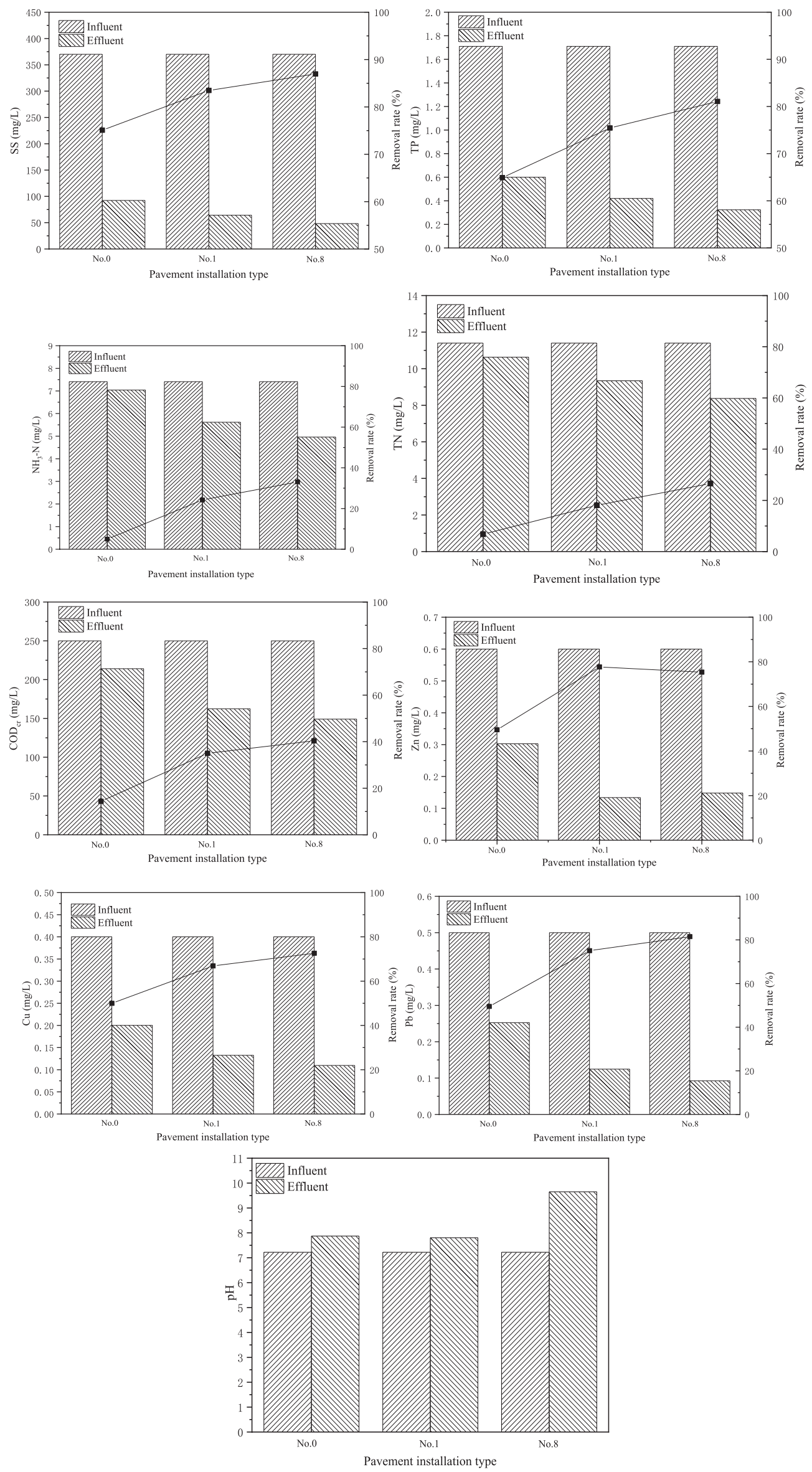

Fig. 5. Removal rates of pollutants for ceramic permeable brick and ceramic permeable brick paving systems filled by $3-5 \mathrm{~cm}$ gravel or cement concrete block 
negative effects of decontamination and decreasing the alkaline environment of the effluent.

\section{Water Purification Effectiveness of Different Particles}

The concentrations and removal rates of pollutants in permeable brick paving systems filled by gravel with different particle sizes are shown in Fig. 6. It can be seen that the effectiveness in removing the pollutants decreased as the particle size of the base layer increased in paving systems No. 1, No. 2 and No. 3, and the removal effectiveness of pavement system No. 4 was high. Studies have shown that the permeable surface brick played a major role in SS removal, and the structural layer formed by the internal filler in
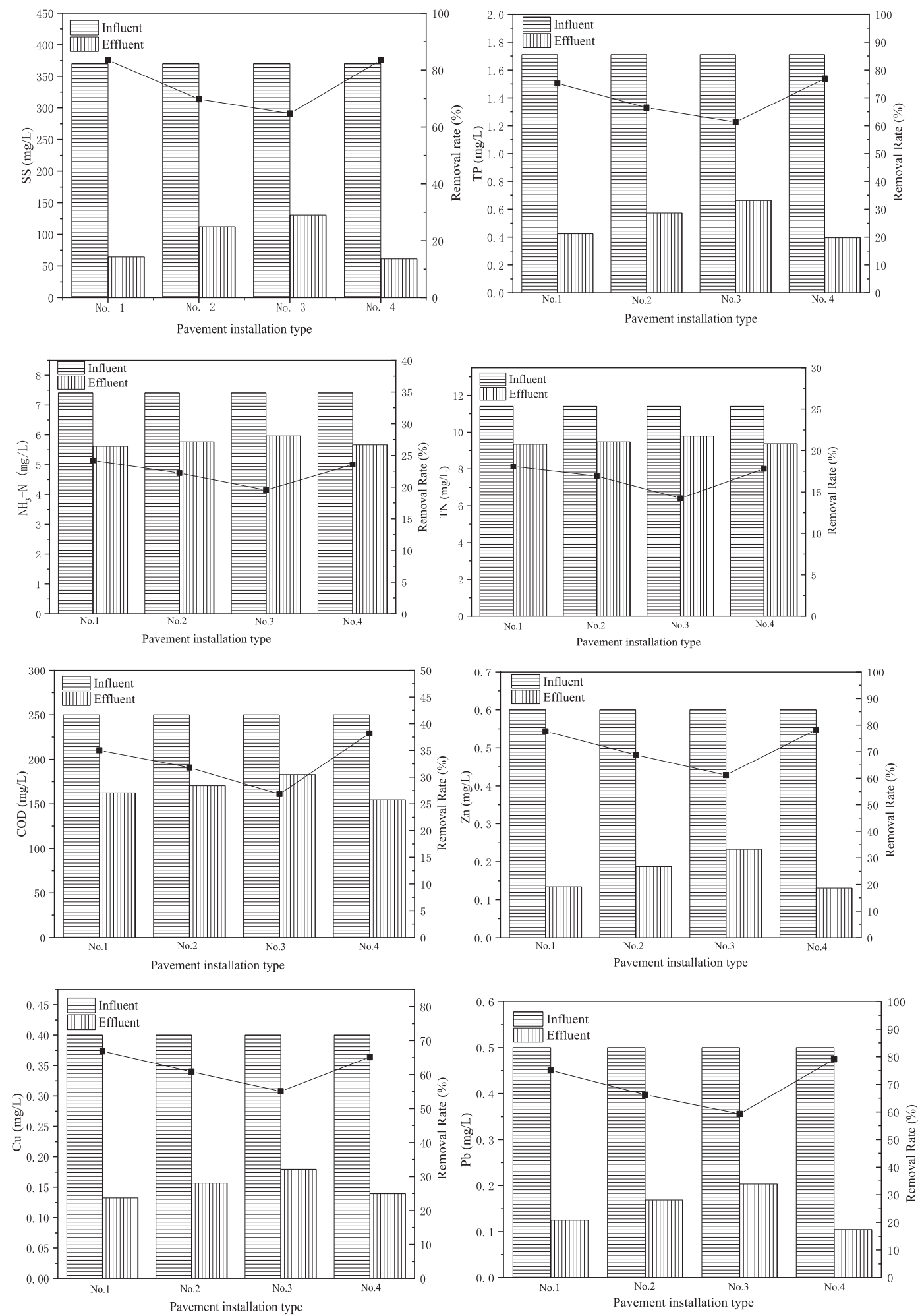

Fig. 6. Concentrations and removal rates of pollutants in permeable brick paving filled by gravel with different particle sizes. 
the frame structure also intercepted SS. The effectiveness of the No. 1 pavement system in removing the SS was obviously better than that of the No. 2 and No. 3 pavement systems. This decrease in the effluent might be due to the physical interception of the suspended solids by the base layer, taking into account that surface layers of all systems were the same. Aside from the surface layer, the internal filler was the main cause of the SS removal rate by the paving system. The large space between the particles created by the larger particle size of the gravel accelerated the seepage velocity of the rainwater, which reduced the removal
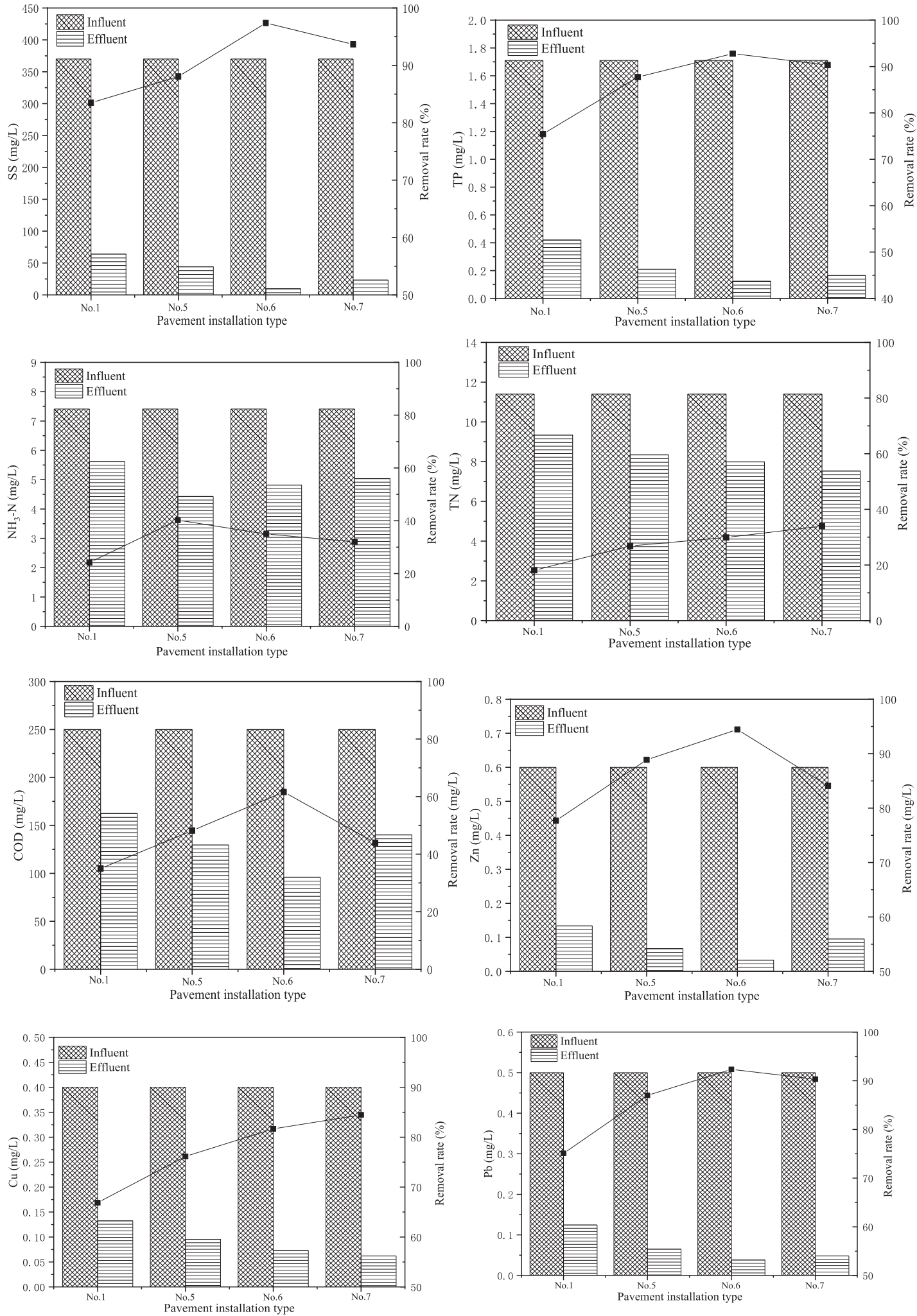

Fig. 7. Concentrations and removal rates of pollutants in permeable brick paving systems filled with different materials. 
efficiency of SS. The TP, $\mathrm{Zn}, \mathrm{Cu}$, and $\mathrm{Pb}$ were usually removed with the SS due to the easy attachment of these substances to suspended particles in water [18-22], so the higher seepage velocity also reduced the removal efficiency of $\mathrm{TP}, \mathrm{Zn}, \mathrm{Cu}$, and $\mathrm{Pb}$. Studies have shown that other soluble pollutants, such as COD, TN, and $\mathrm{NH}_{4}^{+}$-N, were also partially removed by the layer of the particles [23-25]. The removal efficiency of the COD, $\mathrm{TN}, \mathrm{NH}_{4}^{+}-\mathrm{N}$ decreased as the particle size increased, indicating that the filtration of the gravel layer also had a certain effectiveness in removing the dissolved pollutants.

The No. 4 paving system had a good purification effect compared to No. 1, because the void ratio was different in the depth direction in the No. 4 paving system due to the use of graded gravel, which exerted multiple filtering effects and improved the filtering capacity $[12,19]$. The increased filtering capacity of the base layer was beneficial to the physical interception of pollutants by the gravel base layer. The results showed that the use of graded gravel could be as effective as gravel with small particles $(3-5 \mathrm{~cm})$. Thus, graded gravel was recommended to fill the frame structure in actual use. To fully investigate the purification effectiveness of the fillers on the contaminants, the subsequent study uniformly used materials with a small particle size of $3-5 \mathrm{~cm}$, considering that it was difficult to achieve complete consistency in the particle gradation of different materials, but this did not mean that the purification effectiveness of the $3-5 \mathrm{~cm}$ particle size was better than that of the graded gravel.

\section{Water Purification Effectiveness of Different Materials}

The concentrations and removal rates of pollutants in permeable brick paving systems filled with different materials are shown in Fig. 7. From Fig. 7, it can be seen that the removal effectiveness of characteristic pollutants was improved by adjusting the specific fillers, especially for the dissolved pollutants such as $\mathrm{NH}_{4}^{+}-\mathrm{N}$, TN and COD.

The low $\mathrm{NH}_{4}^{+}-\mathrm{N}$ removal rate by the ceramic permeable brick occurred because the dissolved ammonia ions were difficult for the permeable bricks to filter and retain, and the removal of $\mathrm{NH}_{4}^{+}-\mathrm{N}$ was mainly due to adsorption and ion exchange of the $\mathrm{NH}_{4}^{+}-\mathrm{N}$ by the fillers in the permeable brick paving systems $[10,14,19,26]$, the important thing was, the zeolite added to the frame base was more effective than the other fillers in removing $\mathrm{NH}_{4}^{+}-\mathrm{N}$ with the removal rate being $40.42 \%$, which was higher than other fillers. The zeolite reliably relied on the dispersive force of the pore walls and the negative charge of silicate skeleton to adsorb $\mathrm{NH}_{4}^{+}-\mathrm{N}$. [27-29]. Therefore, part of the $\mathrm{NH}_{4}^{+}-\mathrm{N}$ in the rainwater runoff could be effectively removed.

The iron filings added to the frame had the highest removal effectiveness on the TN of all the fillers, which was mainly due to the large amount of the element Fe in the iron filings, which can effectively reduce the $\mathrm{NO}_{3}{ }^{-}-\mathrm{N}$ pollutants, and its adsorption reaction formula was $5 \mathrm{Fe}+2 \mathrm{NO}_{3}^{-}+6 \mathrm{H}_{2} \mathrm{O}=5 \mathrm{Fe}^{2+}+12 \mathrm{OH}^{-}+\mathrm{N}_{2} \uparrow[30]$. This provided a feasible technical path for improving the removal efficiency of $\mathrm{TN}$, that is, optimizing the composition of iron filings and zeolite to remove $\mathrm{NH}_{4}^{+}-\mathrm{N}$ and $\mathrm{NO}_{3}^{-}-\mathrm{N}$, respectively. It was also possible that some of the forms of $\mathrm{NH}_{4}^{+}-\mathrm{N}$ had changed to $\mathrm{NO}_{2}^{-}$ $-\mathrm{N}$ or $\mathrm{NO}_{3}{ }^{-} \mathrm{N}$ during the filtration process, because there was more air and enough oxygen in the well structure, which could promote the nitrification of $\mathrm{NH}_{4}^{+}-\mathrm{N}[14,16]$. Therefore, adding more iron filings might be more beneficial to the removal of nitrogen.

The COD removal rate of the volcanic rock was obviously better than those of zeolite, iron filings and gravel, mainly due to the high content of $\mathrm{Fe}_{2} \mathrm{O}_{3}$ in volcanic rock [31,32], which had good adsorption of the COD. The removal rate between the volcanic rocks and gravel differed by $25.58 \%$ in the case of the same diameter, indicating that the adsorption properties of the materials played a key role in the COD removal and that adding fillers rich in $\mathrm{Fe}_{2} \mathrm{O}_{3}$ could improve the removal rate of COD.

Combined with the foregoing research conclusions, it is inferred that the quality of effluent of the permeable brick paving system can be further improved by optimizing the composition of zeolite, iron filing and volcanic rocks.

\section{Conclusions}

A permeable brick paving system was constructed using the well-shaped frame structure as a novel structure applied to the base layer. Gravel of four different particle sizes and zeolite, volcanic rock and iron filings of the same particle size were added to the base layer, and the role and mechanism of the fillers in the removal of contaminants were discussed. Based on the results from this study, the following conclusions could be drawn.

(1) It is feasible to introduce the well structure in the permeable brick paving system considering the convenience of construction, little negative effects of decontamination and decreasing the alkaline environment of the effluent, the well-shaped frame structure is a new and more environmentally friendly alternative for the base layer of permeable brick paving system pavement

(2) The permeable brick system filled with smalldiameter gravel was more effective than a system filled with large-diameter gravel in removing most conventional pollutants. The void ratio of the filter layer consisting of graded gravel was different in the depth direction, which resulted in multiple filtering effects. Graded gravel of $3-15 \mathrm{~cm}$ could be as effective as small gravel with $3-5 \mathrm{~cm}$ particles.

(3) The permeable brick system filled by zeolite had a high adsorption effect on $\mathrm{NH}_{4}^{+}-\mathrm{N}$, and iron filings 
added could effectively reduce $\mathrm{NO}_{3}^{-}-\mathrm{N}$, while adding fillers rich in iron oxide such as volcanic rock could contribute to COD adsorption. The quality of effluent of the permeable brick paving system could be further improved by optimizing the composition of zeolite, iron filing and volcanic rocks.

\section{Acknowledgements}

This study was supported by the National Natural Science Foundation of China (No. 51608272), the Science and Technology Project of Jiangsu Provincial Construction System (No. 2018ZD203), the Science and Technology Project of Nanjing Municipal Construction System (No. Ks1914), and the Student's Innovative Projects of Nanjing Forestry University (2018NFUSPITP769, 2019NFUSPITP0504) for financial support.

\section{Conflict of Interest}

The authors declare no conflict of interest

\section{References}

1. SOUNTHARARAJAH D.P., LOGANATHAN P., KANDASAMY J.S. Vigneswaran, Removing heavy metals using permeable pavement system with a titanate nano-fibrous adsorbent column as a post treatment. Chemosphere. 168, 467, 2017.

2. LIU J., YAN H.X., LIAO Z.Y., ZHANG K., SCHMIDT A.R., TAO T. Laboratory analysis on the surface runoff pollution reduction performance of permeable pavements. Science of the Total Environment. 691, 1, 2019.

3. CHANDRAPPA A.K., BILIGIRI K.P. Pervious concrete as a sustainable pavement material research findings and future prospects: a state-of-the-art review. Construction and Building Materials. 111, 262, 2016.

4. RALLA A., SAADEH S. Sustainable Mitigation of Stormwater Runoff through Fully Permeable Pavement. National Center for Sustainable Transportation, University of California, Davis Research Report. 2018.

5. CHEN J.Q., THELLER L., GITAU M.W., ENGEL B.A., HARBOR J.M. Urbanization impacts on surface runoff of States the contiguous United States, Journal of Environmental Management. 187, 470, 2017.

6. DU J.K., QIAN L., RUI H.Y., ZUO T.H., ZHENG D.P., XU Y.P., XU C.Y. Assessing the effects of urbanization on annual runoff and flood events using an integrated hydrological modeling system for Qinhuai River basin, China. Journal of Hydrology. 464, 127, 2012.

7. LI C.H., PENG C., CHIANG P.C., CAI Y.P., WANG X., YANG Z.F. Mechanisms and applications of green infrastructure practices forstormwater control: A review. Journal of Hydrology. 568, 626, 2019.

8. KURUPPU U., RAHMAN A., SATHASIVAN A. Enhanced denitrification by design modifications to the standard permeable pavement structure. Journal of cleaner production. 237, 117721, 2019.

9. CHEN J.Q., CHU R.X., WANG H. ZHANG L.C., CHEN, X.D., DU Y.F. Alleviating urban heat island effect using high-conductivity permeable concrete pavement. Journal of cleaner production. 237, 117722, 2019.

10. BEAN E.Z., HUNT W.F., BIDELSPACH D.A. Evaluation of four permeable pavement sites in eastern north carolina for runoff reduction and water quality impact. Journal of Irrigation and Drainage Engineering. 133 (4), 583, 2007.

11. ZHANG Z.Y., LI Z.F., ZHANG X.R., LIU D.Q., LI Z.R., LI H.Y. Systematically Investigated the Influences of Permeable Pavement Materials on the Water Quality of Runoff: Batch and Column Experiments. Water Air and Soil Pollution. 229 (5), 155, 2018.

12. LI H.Y., LI Z.F., ZHANG X.R., LI Z.R., LIU D.Q., LI T.H., ZHANG Z.Y. The effect of different surface materials on runoff quality in permeable pavement systems. Environmental Science and Pollution Research. 24 (26), 21103, 2017.

13. SANNUDO-FONTANEDA L.A., CHARLESWORTH S.M., CASTRO-FRESNO D., ANDRES-VALERI V.C.A., RODRIGUEZ-HERNANDEZ J. Water quality and quantity assessment of pervious pavements performance in experimental car park areas, Water Science and Technology. 69 (7), 1526, 2014.

14. RAZZAGHMANESH M., BORST M. Long-term effects of three types of permeable pavements on nutrient infiltrate concentrations. Science of the Total Environment. 670, 893-901, 2019.

15. WANG H., HE X.W., LIU. T.Q., ZHANG C.H. Analysis on the adsorptive characteristics for ammonia nitrogen and phosphorus of different substrates in constructed wetlands. Fresenius Environmental Bulletin. 20 (11) 2890, 2011.

16. COLLINS K.A., HUNT W.F., HATHAWAY J.M. Side-byside comparison of nitrogen species removal for four types of permeable pavement and standard asphalt in eastern North Carolina, Journal of Hydrology. 15 (6), 512, 2010.

17. DAVIS, A.P., MCCUEN, R. Stormwater Management for Smart Growth, 2005.

18. DRAKE J., BRADFORD A., VAN SETERS T. Winter Effluent Quality from Partial-Infiltration Permeable Pavement Systems, Journal of Environmental Management. 140 (11), 1, 2014.

19. JIANG W., SHA, A.M., XIAO J.J., LI Y.L., HUANG Y. Experimental study on filtration effect and mechanism of pavement runoff in permeable asphalt pavement. Construction and Building Materials. 100, 102, 2015.

20. HATT B.E., FLETCHER T.D., DELETIC A. Treatment performance of gravel filter media: implications for design and application of stormwater infiltration systems. Water Research. 41 (12), 2513, 2007

21. LIU X.F., HICHER P., MURESAN B., SAIYOURI N., HICHER P.Y. Heavy metal retention properties of kaolin and bentonite in a wide range of concentration and different $\mathrm{pH}$ conditions. Applied Clay Science. 119, 365, 2016.

22. LIU J.Y., BORST M. Performances of metal concentrations from three permeable pavement infiltrates, Water Research. 136, 41, 2018.

23. WANG Z., JING Z.Q., KONG Y. Reduction of COD from Micro-Polluted Water through Adsorption of Activated Carbon-Attapulgite Composite Adsorbent. Key Engineering Materials. 450, 445, 2010.

24. WANG Z., ZHANG L.S., JING Z.Q. Adsorption of ammonia from aqueous solution using zeolite-attapulgite nano-pore structure ceramisite. Advanced Materials Research. 105-106, 627, 2010.

25. JING Z.Q., HE R., HU Y., NIU Q.G., CAO S.W., LI Y.Y. Practice of integrated system of biofilter and constructed 
wetland in highly polluted surface water treatment. Ecological Engineering. 75, 462, 2015.

26. WELKER A.L. JENKINS J.K.G., MCCARTHY L., NEMIROVSKY E. Examination of the material found in the pore spaces of two permeable pavements. Journal of Irrigation and Drainage Engineering. 139, 278, 2013.

27. SHIRVANI M., KALBASI M., SHARIATMADARI H., NOURBAKHSH F., NAJAFI B. Sorption-desorption of cadmium in aqueous palygorskite, sepiolite, and calcite suspensions: Isotherm hysteresis. Chemosphere. 65 (11), 2178, 2016.

28. WANG S.B., PENG Y.L. Natural zeolites as effective adsorbents in water and wastewater treatment. Chemical Engineering Journal. 156, 11, 2010.

29. SANCHO I., LICON E.C., VALDERRAMA DE ARESPACOCHAGA N., LOPEZ-PALAU S., CORTINA J.L. Recovery of ammonia from domestic wastewater effluents as liquid fertilizers by integration of natural zeolites and hollow fibre membrane contactors, Science of the Total Environment. 584, 244, 2017.

30. ZHANG J., HAO Z., ZHANG Z., YANG Y.P., XU X.H. Kinetics of nitrate reductive denitrification by nanoscale zero-valent iron. Process Safet and Environmental Protection. 88 (6), 439, 2010.

31. KOUPAI J.A., NEJAD S.S., MOSTAFAZADEH-FARD S., BEHFARNIA K. Reduction of Urban Storm-Runoff Pollution Using Porous Concrete Containing Iron Slag Adsorbent. Journal of Environmental Engineering. 142, 04015072, 2016.

32. FASSMAN E.A., BLACKBOURN S. Urban Runoff Mitigation by a Permeable Pavement System over Impermeable Soils. Journal of Hydrologic Engineering. 15 (6), 475, 2010. 
